\title{
SigCS base: an integrated genetic information resource for human cerebral stroke
}

\author{
Young-Kyu Park ${ }^{1,2}$, Ok Sun Bang ${ }^{3}$, Min-Ho Cha ${ }^{3}$, Jaeheup Kim ${ }^{4}$, John W Cole ${ }^{5}$, Doheon Lee ${ }^{2^{*}}$, Young Joo Kim ${ }^{6 *}$ \\ From 22nd International Conference on Genome Informatics \\ Busan, Korea. 5-7 December 2011
}

\begin{abstract}
Background: To understand how stroke risk factors mechanistically contribute to stroke, the genetic components regulating each risk factor need to be integrated and evaluated with respect to biological function and through pathway-based algorithms. This resource will provide information to researchers studying the molecular and genetic causes of stroke in terms of genomic variants, genes, and pathways.

Methods: Reported genetic variants, gene structure, phenotypes, and literature information regarding stroke were collected and extracted from publicly available databases describing variants, genome, proteome, functional annotation, and disease subtypes. Stroke related candidate pathways and etiologic genes that participate significantly in risk were analyzed in terms of canonical pathways in public biological pathway databases. These efforts resulted in a relational database of genetic signals of cerebral stroke, SigCS base, which implements an effective web retrieval system.

Results: The current version of SigCS base documents 1943 non-redundant genes with 11472 genetic variants and 165 non-redundant pathways. The web retrieval system of SigCS base consists of two principal search flows, including: 1) a gene-based variant search using gene table browsing or a keyword search, and, 2) a pathway-based variant search using pathway table browsing. SigCS base is freely accessible at http://sysbio.kribb.re.kr/sigcs.

Conclusions: SigCS base is an effective tool that can assist researchers in the identification of the genetic factors associated with stroke by utilizing existing literature information, selecting candidate genes and variants for experimental studies, and examining the pathways that contribute to the pathophysiological mechanisms of stroke.
\end{abstract}

\section{Introduction}

Stroke is a heterogeneous complex disease that results from the interaction between genetic and environmental risk factors and has many well-established etiologies [1-5]. It is the second most common cause of death worldwide and is a major cause of acquired disability in survivors [5,6]. Environmental risk factors include smoking, alcohol intake, lack of physical activity, poor diet, and psychosocial stress/depression. Other established risk factors include hypertension, obesity, diabetes mellitus, and cardiovascular disease [2,5]. Several etiological risk factors including arteriovenous malformations,

\footnotetext{
* Correspondence: dhlee@biosoft.kaist.ac.kr; yjkim8@kribb.re.kr

${ }^{2}$ Department of Bio and Brain Engineering, KAIST, Daejeon 305-701, Korea

${ }^{6}$ Genome Resource Center, KRIBB, Daejeon 305-806, Korea

Full list of author information is available at the end of the article
}

atherosclerosis, blood coagulation, sex hormone effects, hyperlipidemia, homocysteine, and inflammation have also been described [1,3-5].

Many genetic studies evaluating stroke pathophysiology and mechanisms have been conducted, resulting in hundreds of genes that appear to be associated with stroke. Most stroke-related genetic variants are causal markers derived using candidate gene approaches $[7,8]$. Stroke-related genetic loci have recently been identified implementing genome-wide association (GWA) studies $[9,10]$. Further, genetic variants related to other stroke etiologies, such as aneurysms [11,12] and diabetes [13], have also been reported.

To understand the contribution of the various risk factors to the mechanism of stroke, the genetic basis of each risk factor must be analyzed and integrated, in
C Biomed Central

C 2011 Park et al; licensee BioMed Central Ltd. This is an open access article distributed under the terms of the Creative Commons Attribution License (http://creativecommons.org/licenses/by/2.0), which permits unrestricted use, distribution, and reproduction in any medium, provided the original work is properly cited. 
terms of biological function and pathway relationships. To this end, an efficient database system that integrates genetic variants and annotated information on stroke and its etiologies is required. Currently, there is no published or established database for this purpose, except the previous work by the author's research group, StrokeBase [14]. In the previous work, cerebrovasular disease-related genes were collected from public databases, text-mining works with the goal to expand the functional information by using protein-protein interaction data and SNP-based genome-wide association study results. However, the system was substantially less informative due to an insufficient number of candidate genes, a lack of cross-links between the different types of the information, and inefficient user interfaces for the retrieval system.

Here we introduce SigCS base, an integrated genetic information resource for human cerebral stroke. SigCS base will allow researchers in molecular biology and genetics who study the causes and mechanisms of cerebral stroke to efficiently evaluate thousands of genomic variants and genes that are associated with stroke and its etiologies, as well as relevant annotated data from public molecular biology databases. By using the various retrieval features of SigCS base, researchers will be able to effectively refer to this information to select candidate genes and variants for their studies, to compare their genetic factors with previously reported results, and to examine the pathways that contribute to the pathological mechanism of stroke by comparing them between stroke and other etiologies.

\section{Methods}

Data source and processing

Online Mendelian Inheritance in Man (OMIM) [15] and Universal Protein Resource (UniProt) [16] were used to retrieve information on stroke- and etiology-related genetic variants; dbSNP [17] for SNP information; UCSC genome [18] for gene structure information, including transcript, exon/intron, coding region, and functional element data on SNPs; HUGO Gene Nomenclature Committee (HGNC) database [19] for standard gene names; Molecular Signatures Database (MSigDB) [20] for pathway and functional gene set information; and OMIM for literature information and PubMed links as raw data sources.

Eleven stroke etiologies/risk factors were selected: hypertension [1-3,21,22], obesity [2,3,23]-known to contribute to both ischemic and hemorrhagic stroke [5] -type 2 diabetes mellitus [2,3,5,22], hyperlipidemia $[3,5,22]$, atherosclerosis $[3,24]$, blood coagulation $[3,4,25]$, vascular inflammation $[4,26,27]$, estrogen effect $[28,29]$, hyperhomocysteinemia $[4,25,30]$ for ischemic stroke, intracranial aneurysm $[1,31]$, and arteriovenous malformations [1,31,32] for hemorrhagic stroke. Then, to construct a variant and gene set, we downloaded stroke- and stroke etiology-related records in XML format from the OMIM database through a refined keyword search (Table 1) and parsed them.

To enhance the variant information, we extracted variant, phenotype, and literature data from the downloaded flat files of UniProt. To add the functional significance of each variant, we extracted gene structural annotations and SNP functional annotations from a downloaded flat file from UCSC genome. We extracted the flank sequences of SNPs from the dbSNP flat file to help researchers' experimental studies.

All gene symbol data was converted to the standard gene symbols of HGNC to ensure compatibility between the datasets.

\section{Pathway analysis}

To attain insight into the biological functions and pathological mechanisms of stroke and its etiologies, we analyzed the biological pathways that significantly overlapped with the curated stroke and etiology gene sets. For this, we counted common genes between the stroke and etiology gene sets and the genes in known canonical pathways in MSigDB [20] and performed statistical testing to assess the significance of the overlaps. An one-tailed version of Fisher's exact test (http://en. wikipedia.org/wiki/Hypergeometric_distribution) based on the hypergeometric distribution $(\mathrm{k}, \mathrm{K}, \mathrm{n}, \mathrm{N})$ of $\mathrm{k}$ overlapping genes in a user gene set of $\mathrm{n}$ genes and the pathway having $\mathrm{K}$ genes in a total gene space of $\mathrm{N}$ genes was used for the statistical test. An adjustment for multiple testing followed by false discovery rate evaluation was performed. For these analyses 639 pathways with including 5385 genes from BioCarta (http:// www.biocarta.com/), KEGG (http://www.genome.jp/ kegg/), and Reactome (http://www.reactome.org/) databases were implemented.

\section{Database implementation}

A relational database using MySQL was constructed implementing a web retrieval system in the PHP language. To manage and service all the derived information an Apache web server on a Linux platform (Dell PowerEdge Server with $22.66 \mathrm{GHz}$ Intel Quad Core Xeon CPUs, 32 GB memory, and 6TB SAS hard drive) was implemented.

\section{Results}

The current version of SigCS base documents 1943 nonredundant genes with 11472 genetic variants and 165 non-redundant pathways (Table 2). The web retrieval system of SigCS base consists of two principal search flows: 1) a gene-based variant search using gene table 
Table 1 Keywords used to retrieve OMIM database for stroke and its etiology related records

\begin{tabular}{|c|c|c|}
\hline Stroke or its etiology & Keywords for OMIM search & $\begin{array}{l}\text { Etiology } \\
\text { Code }\end{array}$ \\
\hline Atherosclerosis & $\begin{array}{c}\text { Atherosclerosis; Atheroscleroses; Fatty Streak, Arterial; Arterial Fatty Streak; Streak, Arterial Fatty; } \\
\text { Atheroma; Atherogenesis }\end{array}$ & ATSC \\
\hline Blood coagulation & Blood Coagulation; Blood Clotting & COAG \\
\hline Cardiovascular Disease & Cardiovascular Disease & CAVD \\
\hline Diabetes mellitus, type 2 & $\begin{array}{l}\text { Ketosis-Resistant Diabetes Mellitus; Non-Insulin-Dependent Diabetes Mellitus; Non Insulin } \\
\text { Dependent Diabetes Mellitus; Noninsulin Dependent Diabetes Mellitus; Type } 2 \text { Diabetes } \\
\text { Mellitus; Slow-Onset Diabetes Mellitus; Slow Onset Diabetes Mellitus; Stable Diabetes Mellitus; } \\
\text { Diabetes Mellitus, Type II; Maturity-Onset Diabetes Mellitus; Maturity Onset Diabetes Mellitus; } \\
\text { MODY; NIDDM; Adult-Onset Diabetes Mellitus }\end{array}$ & T2DM \\
\hline Estrogen effect & Estrogen & ESTR \\
\hline Homocysteine & Homocysteine & HCYS \\
\hline Hyperlipidemia & Hyperlipidemia; Hyperlipemia; Hyperlipidemia; Lipidemia; Lipemia & HLIP \\
\hline Hypertension & Hypertension; High Blood Pressure & HTNS \\
\hline Vascular inflammation/Vasculitis & Inflammation & INFL \\
\hline $\begin{array}{l}\text { Intracranial arteriovenous malformations } \\
\text { (AVM); Aneurysm }\end{array}$ & $\begin{array}{c}\text { Intracranial Aneurysm; Basilar Artery Aneurysm; Cerebral Artery Aneurysm; Berry Aneurysm; } \\
\text { Brain Aneurysm; Cerebral Aneurysm; Intracranial Mycotic Aneurysm; Communicating Artery } \\
\text { Aneurysm; Intracranial Arteriovenous Malformation; AVM Intracranial; Intracranial AVM; Cerebral } \\
\text { Arteriovenous Malformation; Ruptured Intracranial Arteriovenous Malformation }\end{array}$ & IAVM \\
\hline Obesity & Obesity & OBES \\
\hline Stroke & $\begin{array}{c}\text { Stroke; Cerebral Stroke; Brain Vascular Accident; Cerebrovascular Apoplexy; Cerebrovascular } \\
\text { Stroke; CVA; Cerebrovascular Accident; Apoplexy }\end{array}$ & STRK \\
\hline
\end{tabular}

browsing or keyword search, 2) a pathway-based variant search using pathway table browsing. SigCS base is freely accessible at http://sysbio.kribb.re.kr/sigcs.

\section{User interface}

Users can retrieve genetic variant and biological pathway information that are related with stroke and its etiologies in SigCS base through its two principal search flows including: a gene-based variant search (M1 or M2 $\rightarrow 1 \rightarrow 2 \rightarrow 5,6,7,8,9$ or 4 in Figure 1 ) and a pathwaybased variant search $(\mathrm{M} 3 \rightarrow 3 \rightarrow 4 \rightarrow 10$ or 2 in Figure 1$)$. The former uses genes as an entry point of variant information through a gene table browse function or keyword search. The latter uses pathways as an entry point of variant information through a pathway table browse function. The two search flows connect in the middle of the search flows using cross-links between genes and pathways.

\section{Gene-based variant search}

In this search flow methodology, users can retrieve genetic variant information that is related to stroke and its etiologies through a table browse or keyword search function. To do so, at first users can peruse the resulting gene list in table format by choosing the 'Browse'

Table 2 Statistics on the information in SigCS base

\begin{tabular}{|c|c|c|c|c|}
\hline No. & Stroke or Etiology & \# of Genes & \# of Variants & \# of Sig. Pathways* \\
\hline 1 & Stroke & 236 & 1609 & 18 \\
\hline 2 & Atherosclerosis & 200 & 891 & 19 \\
\hline 3 & Cardiovascular disease & 143 & 501 & 9 \\
\hline 4 & Coagulation, blood & 47 & 732 & 19 \\
\hline 5 & Estrogen & 353 & 851 & 6 \\
\hline 6 & Hypercysteinemia & 90 & 118 & 2 \\
\hline 7 & Hyperlipidemia & 102 & 333 & 10 \\
\hline 8 & Hypertension & 521 & 2177 & 13 \\
\hline 9 & Intracranial arteriovenous malformations (including intracranial aneurysm) & 60 & 182 & 11 \\
\hline 10 & Inflammation & 696 & 1354 & 94 \\
\hline 11 & Obesity & 412 & 1121 & 27 \\
\hline 12 & Diabetes mellitus, type 2 & 208 & 1603 & 19 \\
\hline Total & Stroke + All etiologies & $3068(1943)^{\dagger}$ & 11472 & $247(165)^{\dagger}$ \\
\hline
\end{tabular}

* Pathways with the FDR q-values of less than 0.05 .

† Numbers in ( ) are counts for non-redundant genes or pathways over the etiologies. 


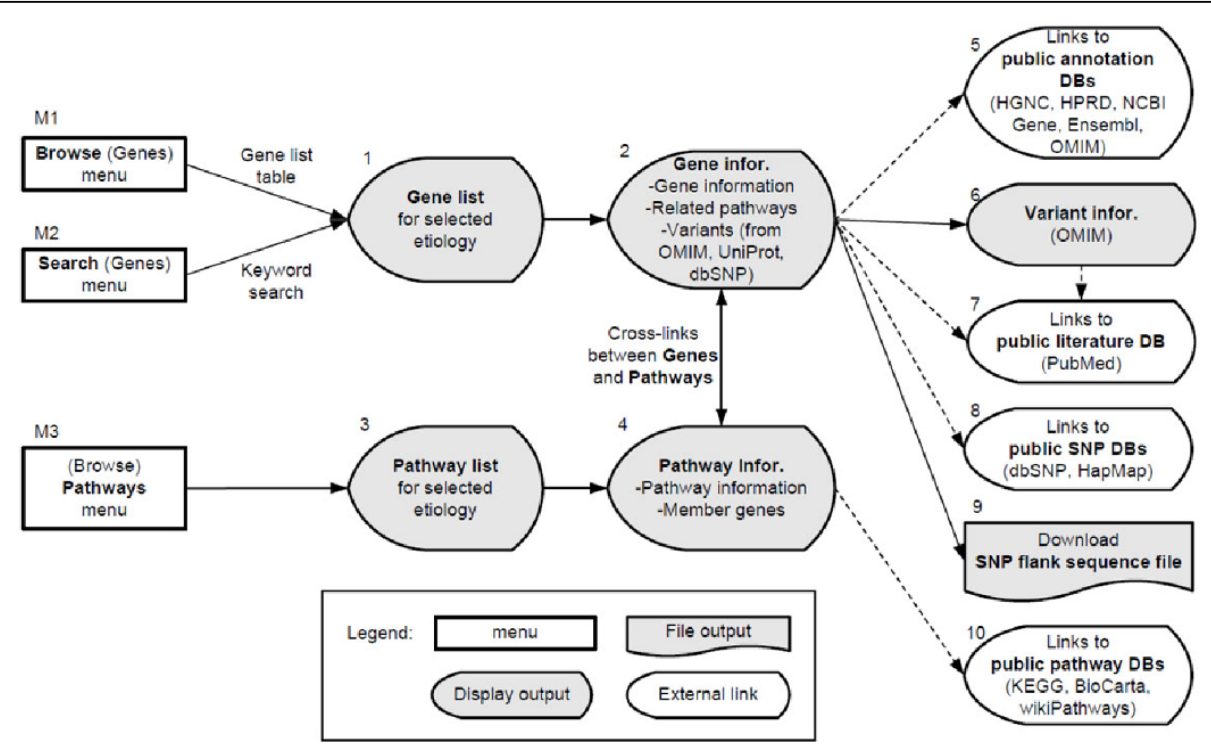

Figure 1 Two main search flows in SigCS base. Users can retrieve stroke and its etiology related genetic variant and biological pathway information through the two principal search flows of SigCS base: a gene-based variant search (M1 or M2 $\rightarrow 1 \rightarrow 2 \rightarrow 5,6,7,8,9$ or 4) and a pathway-based variant search (M3 $\rightarrow 3 \rightarrow 4 \rightarrow 10$ or 2$)$.

menu (M1 in Figure 1) or search the genes by keyword search on the gene symbols or gene descriptions stored in SigCS base at the keyword search page (A in Figure 2) by choosing the 'Search' menu (M2 in Figure 1).

After examining the gene list and description by the gene table browsing or keyword search, users can click a gene symbol of interest and retrieve the gene information page, comprising a gene information table, an OMIM-originated variant table, a UniProt-originated variant table, and a dbSNP-originated variant table ( $\mathrm{B}$ in Figure 2).

The gene information table lists basic data on the gene, hyperlinks to functional annotation databases, and data on the biological pathway to which the gene is assigned. The hyperlinks connect to public annotation databases, including Entrez Gene [33], HGNC, OMIM, Ensembl [34], and HPRD [35]. Clicking the link on a pathway name generates a pathway information page that contains detailed gene pathways, hyperlinks to the source pathway annotation database, a list of other genes that are assigned to the same pathway, and pvalues for pathway assignments (B in Figure 3).

The OMIM-originated variant table displays the variants in the selected gene and related phenotype information. Links on the variant name generates a page that contains detailed variant information and shows experimental data, phenotype data, and references on that variant.

The UniProt-originated variant table shows nonsynonymous variants, ordered by amino acid coordinates in the protein, for the selected gene, as well as amino acid pairs that correspond to the variants, related phenotypes, and PubMed links.

The dbSNP-originated variant table lists the SNPs, based on the genomic structure of the gene, ordered by coding strand. The structure of the gene includes the 2K upstream base pairs, exons, introns, 5' UTR, 3' UTR, and 500 base-pair downstream region. Each SNP information block is composed of a genomic coordinate (in base pairs) on the chromosome, the rsID, mutation function, and links to the dbSNP and HapMap databases [36]. Researchers can evaluate the function or usability of each SNP in experimental studies using the provided information on function, detailed SNP information from dbSNP, and linkage disequilibrium and tag SNP data from HapMap. A SNP flank sequence file can be downloaded selectively for further study.

\section{Pathway-based variant search}

In this search flow, users can retrieve pathways and gene sets that statistically analyzed to contribute functionally to stroke or each etiology through the 'Pathways' menu (M3 in Figure 1). This flow is helpful in understanding the role of genes or variants when the relationships between the genes and stroke or its etiologies are obscure. By selecting the combo box at the top of the table at the pathway browse page, a table lists biological pathways that are statistically related to stroke or its etiologies, ordered by p-value and q-value (A in Figure 3). The link on the p-value generates a page that contains detailed pathway information, hyperlinks to the source pathway annotation database, and a list of other genes that are assigned to that 


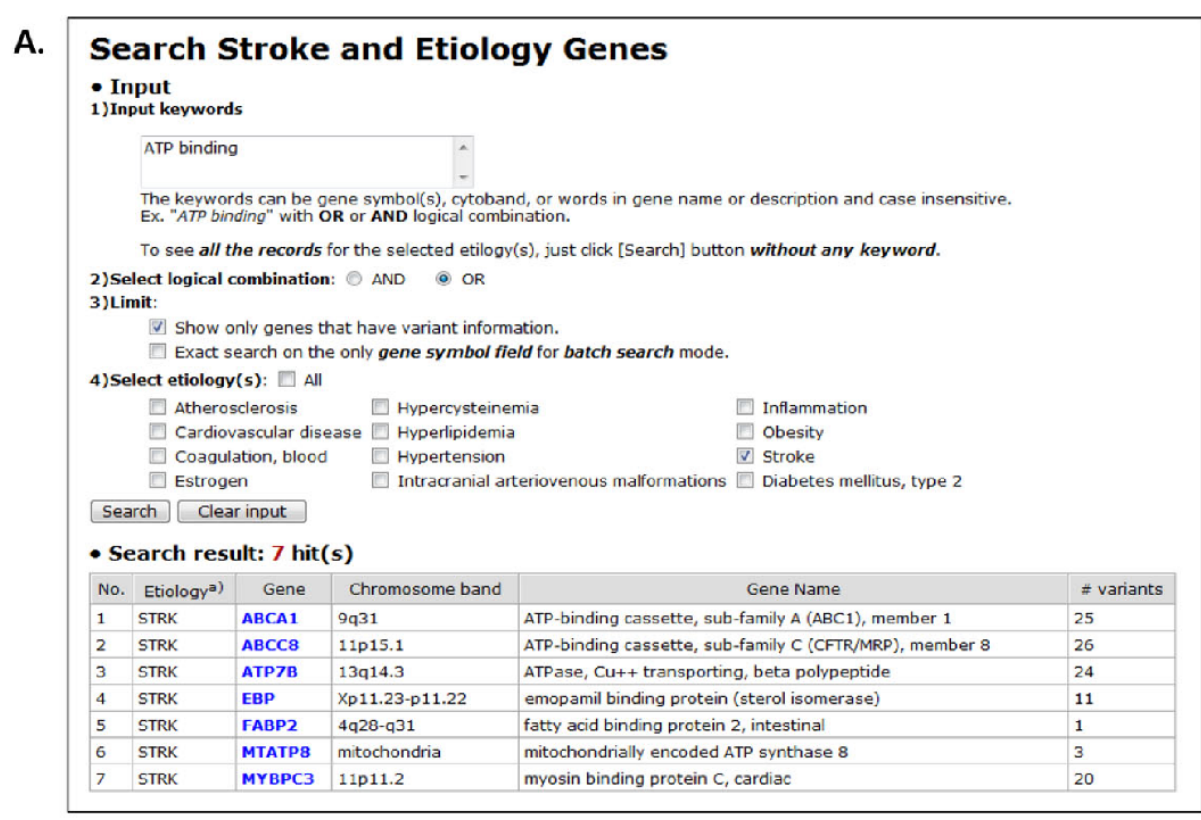

B. Variants in ABCA1 gene SigCs base:

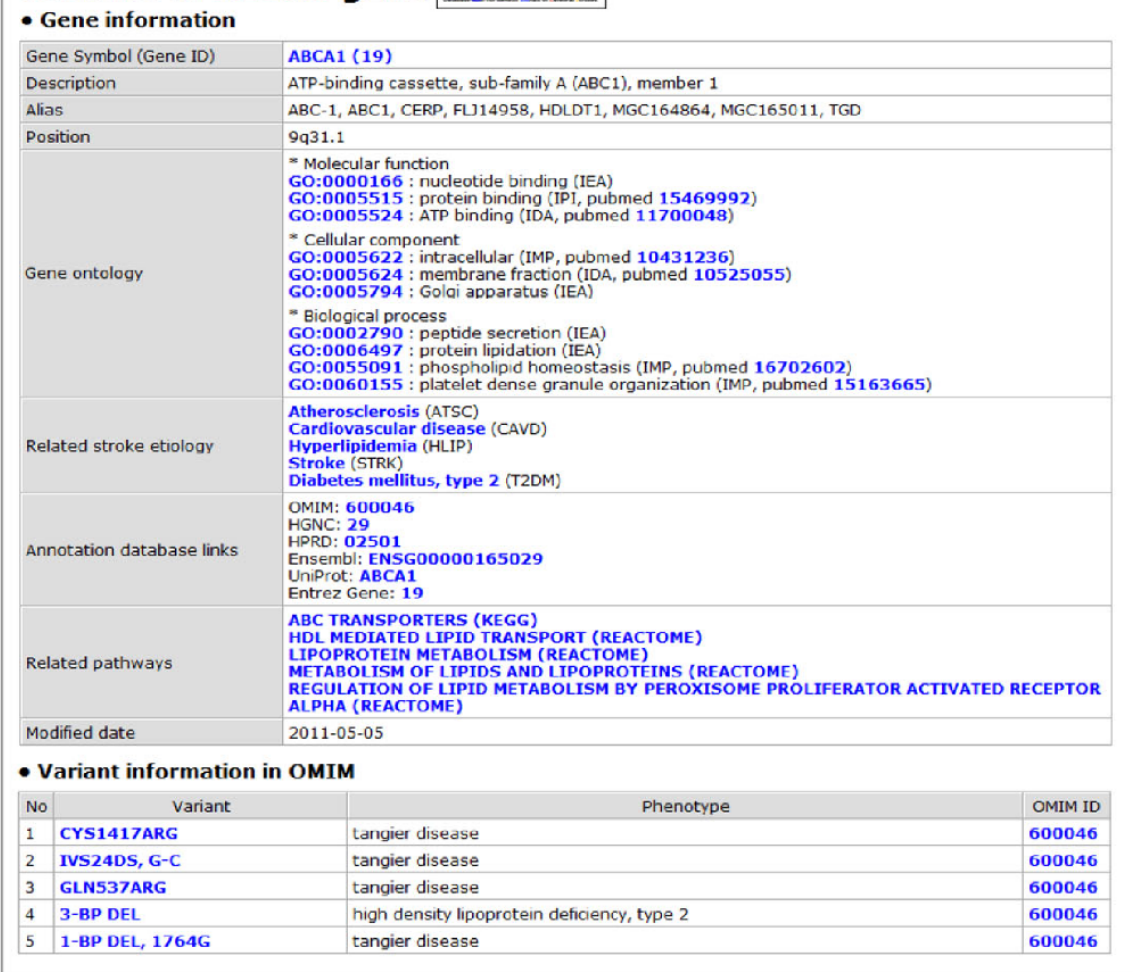

Figure 2 Screenshots for the keyword search page and a gene and variant information page in SigCS base web interface. The keyword search for the stroke and its etiology related genetic variant information in SigCS base is available at the keyword search page. Some useful user options including simple logical combination, limitation of search in terms of the existence of variants, batch search, and a multiple selection of etiologies to be searched are provided (Panel A). Gene and variant information page shows a gene information table, an OMIM-originated variant table, a UniProt-originated variant table, and a dbSNP-originated variant table (Panel B). In the figure, only the gene information table and an OMIM-originated variant table are shown. 


\section{A. Pathways for Stroke and Etiology Genes}

* Select the etiology name: Stroke

* 34 pathways are retrieved.

\begin{tabular}{|c|c|c|c|c|c|c|c|}
\hline No. & Etiology $y^{a)}$ & Pathway (Database) & Description & $\begin{array}{l}\text { Genes in } \\
\text { pathway }\end{array}$ & $\begin{array}{c}\text { Genes } \\
\text { overlapped }\end{array}$ & $\mathrm{p}$-value ${ }^{\mathrm{b})}$ & q-value ${ }^{c \text { ) }}$ \\
\hline 1 & STRK & $\begin{array}{l}\text { LIPOPROTEIN METABOLISM } \\
\text { (REACTOME) }\end{array}$ & $\begin{array}{l}\text { Genes involved in Lipoprotein } \\
\text { metabolism }\end{array}$ & 27 & 9 & $1.8 \mathrm{e}-7$ & $1.5 e-4$ \\
\hline 2 & STRK & $\begin{array}{l}\text { INTRINSIC PATHWAY } \\
\text { (BIOCARTA) }\end{array}$ & $\begin{array}{l}\text { Intrinsic Prothrombin } \\
\text { Activation Pathway }\end{array}$ & 23 & 8 & $6.0 \mathrm{e}-7$ & $2.5 e-4$ \\
\hline 3 & STRK & $\begin{array}{l}\text { FORMATION OF FIBRIN CLOT } \\
\text { CLOTIING CASCADE } \\
\text { (REACTOME) }\end{array}$ & $\begin{array}{l}\text { Genes involved in Formation } \\
\text { of Fibrin Clot (Clotting } \\
\text { Cascade) }\end{array}$ & 32 & 9 & $9.0 \mathrm{e}-7$ & $2.5 e-4$ \\
\hline 4 & STRK & $\begin{array}{l}\text { EXTRINSIC PATHWAY } \\
\text { (BIOCARTA) }\end{array}$ & $\begin{array}{l}\text { Extrinsic Prothrombin } \\
\text { Activation Pathway }\end{array}$ & 13 & 6 & $2.4 \mathrm{e}-6$ & $4.8 e-4$ \\
\hline 5 & STRK & AMI PATHWAY (BIOCARTA) & Acute Myocardial Infarction & 20 & 7 & $3.0 e-6$ & $4.8 \mathrm{e}-4$ \\
\hline 6 & STRK & $\begin{array}{l}\text { COMPLEMENT AND } \\
\text { COAGULATION CASCADES } \\
\text { (KEGG) }\end{array}$ & $\begin{array}{l}\text { Complement and coagulation } \\
\text { cascades }\end{array}$ & 69 & 12 & $3.4 e^{-6}$ & $4.8 e-4$ \\
\hline 7 & STRK & COMMON PATHWAY (REACTOME) & $\begin{array}{l}\text { Genes involved in Common } \\
\text { Pathway }\end{array}$ & 14 & 6 & $4.0 \mathrm{e}-6$ & $4.8 e-4$ \\
\hline 8 & STRK & $\begin{array}{l}\text { GAMMA CARBOXYLATION } \\
\text { TRANSPORT AND AMINO } \\
\text { TERMINAL CLEAVAGE OF } \\
\text { PROTEINS (REACTOME) }\end{array}$ & $\begin{array}{l}\text { Genes involved in Gamma- } \\
\text { carboxylation, transport, and } \\
\text { amino-terminal cleavage of } \\
\text { proteins }\end{array}$ & 10 & 5 & $1.1 \mathrm{e}-5$ & $1.1 \mathrm{e}-3$ \\
\hline 9 & STRK & $\begin{array}{l}\text { CHYLOMICRON MEDIATED LIPID } \\
\text { TRANSPORT (REACTOME) }\end{array}$ & $\begin{array}{l}\text { Genes involved in } \\
\text { Chylomicron-mediated lipid } \\
\text { transport }\end{array}$ & 17 & 6 & $1.5 e-5$ & $1.2 e-3$ \\
\hline 10 & STRK & $\begin{array}{l}\text { BRANCHED CHAIN AMINO ACID } \\
\text { CATABOLISM (REACTOME) }\end{array}$ & $\begin{array}{l}\text { Genes involved in Branched- } \\
\text { chain amino acid catabolism }\end{array}$ & 17 & 6 & $1.5 e-5$ & $1.2 \mathrm{e}-3$ \\
\hline
\end{tabular}

\section{B. KEGG COMPLEMENT AND COAGULATION SigCS base \\ CASCADES pathway}

\begin{tabular}{|c|c|}
\hline Etiology $\mathrm{y}^{\mathrm{a})}$ & STRK \\
\hline Pathway & $\begin{array}{l}\text { COMPLEMENT AND COAGULATION CASCADES (KEGG) } \\
\text { Complement and coagulation cascades }\end{array}$ \\
\hline Genes in Pathway & $\begin{array}{l}69 \text { (A2M, MASP1, MASP2, F13A1, C1QC, SERPINA5, CD46, SERPINE1, CFH, SERPINA1, CFI, CFD, KNG1, } \\
\text { ZNF160, F12, F10, C5AR1, C4A, C4B, F8, F9, SERPING1, F7, PROC, PLAUR, C8G, C1QA, C8A, C1QB, } \\
\text { C8B, THBD, F5, SERPINF2, F3, F2, TFPI, PROS1, C3AR1, MBL2, CXCL10, C9, C3, PSMA7, C5, C1R, } \\
\text { BDKRB1, C1S, BDKRB2, F13B, FGG, FGA, FGB, KLKB1, SERPINC1, C2, PLAT, CR1, CR2, CFB, C4BPB, } \\
\text { C4BPA, PLG, VWF, CD55, CD59, SERPIND1, CPB2, PLAU, F2R) }\end{array}$ \\
\hline Genes overlapped & 12 (A2M, C2, CFB, F12, F2, F5, FGA, FGB, PLAU, PLG, PROC, PROS1) \\
\hline Overlap ratio & 0.173913 \\
\hline p-value & $3.4 \mathrm{e}-6$ \\
\hline q-value for FDR control & $4.8 \mathrm{e}-4$ \\
\hline \multicolumn{2}{|c|}{$\begin{array}{l}\text { a) Etiology codes: } \\
\text { "STRK" for Stroke; } \\
\text { "ATSC" for Atherosclerosis; } \\
\text { "CAVD" for Cardivascular disease; } \\
\text { "COAG" for Coagulation, blood; } \\
\text { "ESTR" for Estrogen; } \\
\text { "HCYS" for Hypercysteinemia; } \\
\text { "HLIP" for Hyperlipidemia; } \\
\text { "HTNS" for Hypertension; } \\
\text { "IAVM" for Intracranial arteriovenous malformations (includes intracranial aneurysm); } \\
\text { "INFL" for Inflammation; } \\
\text { "OBES" for Obesity; } \\
\text { "T2DM" for Diabetes mellitus, type 2. }\end{array}$} \\
\hline
\end{tabular}

Figure 3 Screenshots for the pathway browse page and a detailed pathway information page. Users can retrieve pathways and gene sets contributable for stroke or each etiology at the pathway browse page (Panel A) and get the detailed pathway information (Panel B) by clicking the link on the p-value of a pathway.

pathway (B in Figure 3). The links on the gene symbols in the overlapping gene list provide crosslinks to gene information pages; thus, more efficient gene variant searches can be undertaken.

\section{Conclusions}

SigCS base is an effective user-friendly tool designed to assist researchers in the identification of the molecular and genetic factors associated with stroke. As described, 
SigCS base comprehensively implements numerous genetic databases, including OMIM [15], UniProt [16], dbSNP [17], UCSC genome [18], HGNC database [19], MSigDB [20], providing detailed variant, gene and pathway information to maximize the accuracy of the results produced. These results are further enhanced by including data regarding established stroke etiologies and risk factors, including: hypertension, obesity, type 2 diabetes mellitus, hyperlipidemia, atherosclerosis, blood coagulation, vascular inflammation, estrogen effects, hyperhomocysteinemia, intracranial aneurysms, and arteriovenous malformations.

While highly useful in its current form, SigCS base will be updated periodically as the molecular and pathophysiological understanding of stroke grows with regard to function and as more database content becomes available. For example, in the next SigCS base update, PubMed will be used as the raw data source for variant information rather than OMIM as currently implemented. While OMIM is accurate, the information content is often delayed as compared to PubMed. We also plan to employ text-mining techniques and manual curation to extract gene and variant information, in an effort to retrieve greater and more precise content. Our planned SigCS base content updates will not only provide an improved list of stroke etiologies and risk factor data, but will also increase accuracy by merging certain etiologies that share pathological causalities and adding new etiologies that contribute to stroke. The genetic variants, genes and pathway relationships as derived from more reliable etiologies will provide a more accurate understanding and insight towards the mechanisms of stroke. Users' comments and suggestions for additional features of interest are welcomed.

\section{Acknowledgements}

This work was supported by a grant (K09200) from the Korea Institute of Oriental Medicine (KIOM), in part by a grant (2010-0012810) from the National Research Foundation of Korea (NRF). DL was supported by the World Class University program (R32-2008-000-10218-0) of the Ministry of Education, Science and Technology through the National Research Foundation of Korea.

This article has been published as part of BMC Systems Biology Volume 5 Supplement 2, 2011: 22nd International Conference on Genome Informatics: Systems Biology. The full contents of the supplement are available online at http://www.biomedcentral.com/1752-0509/5?issue=S2.

\section{Author details \\ 'Medical Genome Research Center, KRIBB, Daejeon 305-806, Korea. ${ }^{2}$ Department of Bio and Brain Engineering, KAIST, Daejeon 305-701, Korea. ${ }^{3}$ Department of Medical Research, KIOM, Daejeon 305-811, Korea. ${ }^{4}$ Cogent Biotechnology Inc., Rockville, MD 20850, USA. ${ }^{5}$ Maryland Stroke Center, Department of Neurology, Baltimore Veterans Affairs Medical Center and the University of Maryland School of Medicine, Baltimore MD 21201-1559, USA. ${ }^{6}$ Genome Resource Center, KRIBB, Daejeon 305-806, Korea.}

\section{Authors' contributions}

YP, DL, and YJK conceived the study and designed functions. YP and YJK implemented core programs and web interfaces. OSB, MC, JK, and JWC selected etiology, curated data and constructed database. DL and YJK directed the investigation. YP, DL, and YJK wrote the manuscript. All authors read and approved the final manuscript.

\section{Competing interests}

The authors declare that they have no competing interests.

Published: 14 December 2011

\section{References}

1. Amarenco P, Bogousslavsky J, Caplan LR, Donnan GA, Hennerici MG: Classification of stroke subtypes. Cerebrovasc Dis 2009, 27:493-501.

2. Rundek T, Sacco RL: Risk factor management to prevent first stroke. Neurol Clin 2008, 26:1007-1045, ix.

3. Rubattu S, Giliberti R, Volpe M: Etiology and pathophysiology of stroke as a complex trait. Am J Hypertens 2000, 13:1139-1148.

4. Ay H, Benner T, Arsava EM, Furie KL, Singhal AB, Jensen MB, Ayata C, Towfighi A, Smith EE, Chong JY, Koroshetz WJ, Sorensen AG: A computerized algorithm for etiologic classification of ischemic stroke: the Causative Classification of Stroke System. Stroke 2007, 38:2979-2984.

5. O'Donnell MJ, Xavier D, Liu L, Zhang H, Chin SL, Rao-Melacini P, Rangarajan S, Islam S, Pais P, McQueen MJ, Mondo C, Damasceno A, LopezJaramillo P, Hankey GJ, Dans AL, Yusoff K, Truelsen T, Diener HC, Sacco RL, Ryglewicz D, Czlonkowska A, Weimar C, Wang X, Yusuf S, INTERSTROKE investigators: Risk factors for ischaemic and intracerebral haemorrhagic stroke in 22 countries (the INTERSTROKE study): a case-control study. Lancet 2010, 376:112-123.

6. Feigin $\mathrm{VL}$ : Stroke in developing countries: can the epidemic be stopped and outcomes improved? Lancet Neurol 2007, 6:94-97.

7. Fornage M: Genetics of stroke. Curr Atheroscler Rep 2009, 11:167-174.

8. Matarin M, Singleton A, Hardy J, Meschia J: The genetics of ischaemic stroke. J Intern Med 2010, 267:139-155.

9. Lanktree MB, Dichgans M, Hegele RA: Advances in genomic analysis of stroke: what have we learned and where are we headed? Stroke 2010, 41:825-832.

10. Matarín M, Brown WM, Scholz S, Simón-Sánchez J, Fung HC, Hernandez $D$, Gibbs JR, De Vrieze FW, Crews C, Britton A, Langefeld CD, Brott TG, Brown RD Jr, Worrall BB, Frankel M, Silliman S, Case LD, Singleton A, Hardy JA, Rich SS, Meschia JF: A genome-wide genotyping study in patients with ischaemic stroke: initial analysis and data release. Lancet Neurol 2007, 6:414-420.

11. Bilguvar $K$, Yasuno $K$, Niemelä $M$, Ruigrok $Y M$, von Und Zu Fraunberg $M$, van Duijn CM, van den Berg LH, Mane S, Mason CE, Choi M, Gaál E, Bayri Y, Kolb L, Arlier Z, Ravuri S, Ronkainen A, Tajima A, Laakso A, Hata A, Kasuya H, Koivisto T, Rinne J, Ohman J, Breteler MM, Wijmenga C, State MW, Rinkel GJ, Hernesniemi J, Jäs̈keläinen JE, Palotie A, Inoue I, Lifton RP, Günel M: Susceptibility loci for intracranial aneurysm in European and Japanese populations. Nat Genet 2008, 40:1472-1477.

12. Peck G, Smeeth L, Whittaker J, Casas JP, Hingorani A, Sharma P: The genetics of primary haemorrhagic stroke, subarachnoid haemorrhage and ruptured intracranial aneurysms in adults. PLoS One 2008, 3:e3691.

13. Sladek R, Rocheleau G, Rung J, Dina C, Shen L, Serre D, Boutin P, Vincent D, Belisle A, Hadjadj S, Balkau B, Heude B, Charpentier G, Hudson TJ, Montpetit A, Pshezhetsky AV, Prentki M, Posner Bl, Balding DJ, Meyre D, Polychronakos C, Froguel P: A genome-wide association study identifies novel risk loci for type 2 diabetes. Nature 2007, 445:881-885.

14. Kim YU, Kim IH, Bang OS, Kim YJ: StrokeBase: a database of cerebrovascular disease-related candidate genes. Genomics \& Informatics 2008, 6:153-156.

15. Amberger J, Bocchini CA, Scott AF, Hamosh A: McKusick's Online Mendelian Inheritance in Man (OMIM). Nucleic Acids Res 2009, 37: D793-D796.

16. UniProt consortium: The Universal Protein Resource (UniProt) in 2010. Nucleic Acids Res 2010, 38:D142-D148.

17. Sherry ST, Ward MH, Kholodov M, Baker J, Phan L, Smigielski EM, Sirotkin K: dbSNP: the NCBI database of genetic variation. Nucleic Acids Res 2001, 29:308-311.

18. Rhead B, Karolchik D, Kuhn RM, Hinrichs AS, Zweig AS, Fujita PA, Diekhans M, Smith KE, Rosenbloom KR, Raney BJ, Pohl A, Pheasant M, Meyer LR, Learned K, Hsu F, Hillman-Jackson J, Harte RA, Giardine B, 
Dreszer TR, Clawson H, Barber GP, Haussler D, Kent WJ: The UCSC Genome Browser database: update 2010. Nucleic Acids Res 2010, 38:D613-619.

19. Povey S, Lovering R, Bruford E, Wright M, Lush M, Wain H: The HUGO Gene Nomenclature Committee (HGNC). Hum Genet 2001, 109:678-680.

20. Subramanian A, Tamayo P, Mootha VK, Mukherjee S, Ebert BL, Gillette MA, Paulovich A, Pomeroy SL, Golub TR, Lander ES, Mesirov JP: Gene set enrichment analysis: a knowledge-based approach for interpreting genome-wide expression profiles. Proc Natl Acad Sci U S A 2005, 102:15545-15550.

21. Veglio F, Paglieri C, Rabbia F, Bisbocci D, Bergui M, Cerrato P: Hypertension and cerebrovascular damage. Atherosclerosis 2009, 205:331-341.

22. Lewis A, Segal A: Hyperlipidemia and primary prevention of stroke: does risk factor identification and reduction really work? Curr Atheroscler Rep 2010, 12:225-229.

23. Towfighi A, Zheng L, Ovbiagele B: Weight of the obesity epidemic: rising stroke rates among middle-aged women in the United States. Stroke 2010, 41:1371-1375.

24. Li C, Engstrom G, Berglund G, Janzon L, Hedblad B: Incidence of ischemic stroke in relation to asymptomatic carotid artery atherosclerosis in subjects with normal blood pressure. A prospective cohort study. Cerebrovasc Dis 2008, 26:297-303.

25. Stankovic S, Majkic-Singh N: Genetic aspects of ischemic stroke: coagulation, homocysteine, and lipoprotein metabolism as potential risk factors. Crit Rev Clin Lab Sci 2010, 47:72-123.

26. Sirico G, Spadera L, De Laurentis M, Brevetti G: Carotid artery disease and stroke in patients with peripheral arterial disease. The role of inflammation. Monaldi Arch Chest Dis 2009, 72:10-17.

27. Kinlay S, Schwartz GG, Olsson AG, Rifai N, Szarek M, Waters DD, Libby P, Ganz P: Inflammation, statin therapy, and risk of stroke after an acute coronary syndrome in the MIRACL study. Arterioscler Thromb Vasc Biol 2008, 28:142-147.

28. Carwile E, Wagner AK, Crago E, Alexander SA: Estrogen and stroke: a review of the current literature. J Neurosci Nurs 2009, 41:18-25.

29. de Lecinãna MA, Egido JA, Fernández C, Martínez-Vila E, Santos S, Morales A, Martínez E, Pareja A, Alvarez-Sabín J, Casado I, PIVE Study Investigators of the Stroke Project of the Spanish Cerebrovascular Diseases Study Group: Risk of ischemic stroke and lifetime estrogen exposure. Neurology 2007, 68:33-38.

30. Tascilar N, Ekem S, Aciman E, Ankarali H, Mungan G, Ozen B, Unal A: Hyperhomocysteinemia as an independent risk factor for cardioembolic stroke in the Turkish population. Tohoku J Exp Med 2009, 218:293-300.

31. Herzig R, Bogousslavsky J, Maeder P, Maeder-Ingvar M, Reichhart M, Urbano LA, Leemann B: Intracranial arterial and arteriovenous malformations presenting with infarction. Lausanne Stroke Registry study. Eur J Neurol 2005, 12:93-102.

32. Redekop G, TerBrugge K, Montanera W, Willinsky R: Arterial aneurysms associated with cerebral arteriovenous malformations: classification, incidence, and risk of hemorrhage. J Neurosurg 1998, 89:539-546.

33. Maglott D, Ostell J, Pruitt KD, Tatusova T: Entrez Gene: gene-centered information at NCBI. Nucleic Acids Res 2007, 35:D26-31.

34. Spudich GM, Fernandez-Suarez XM: Touring Ensembl: a practical guide to genome browsing. BMC Genomics 2010, 11:295.

35. Keshava Prasad TS, Goel R, Kandasamy K, Keerthikumar S, Kumar S, Mathivanan S, Telikicherla D, Raju R, Shafreen B, Venugopal A Balakrishnan L, Marimuthu A, Banerjee S, Somanathan DS, Sebastian A, Rani S, Ray S, Harrys Kishore CJ, Kanth S, Ahmed M, Kashyap MK, Mohmood R, Ramachandra YL, Krishna V, Rahiman BA, Mohan S, Ranganathan P, Ramabadran S, Chaerkady R, Pandey A: Human Protein Reference Database-2009 update. Nucleic Acids Res 2009, 37:D767-772.

36. Myers S, Bottolo L, Freeman C, McVean G, Donnelly P: A fine-scale map of recombination rates and hotspots across the human genome. Science 2005, 310:321-324.

\section{doi:10.1186/1752-0509-5-S2-S10}

Cite this article as: Park et al:: SigCS base: an integrated genetic information resource for human cerebral stroke. BMC Systems Biology 2011 5(Suppl 2):S10.

\section{Submit your next manuscript to BioMed Central and take full advantage of:}

- Convenient online submission

- Thorough peer review

- No space constraints or color figure charges

- Immediate publication on acceptance

- Inclusion in PubMed, CAS, Scopus and Google Scholar

- Research which is freely available for redistribution

Submit your manuscript at www.biomedcentral.com/submit
Biomed Central 